\title{
Happiness at Workplace
}

\section{Fitria Rahmi ${ }^{1}$}

${ }^{1}$ Psychology departmen,Faculty of medicine, Andalas University, Padang, $\square$ (e-mail)

fitriarahmi01@gmail.com

\begin{abstract}
Entering the 21st century, the company no longer focuses on the expertise that employees have, but rather on optimizing the quality and function, as well as the positive work experience that employees have. This current situation shows that happiness is one of the important issues that need to be considered especially in the world environment. Happiness in the work place refers to employee satisfaction with their works and lives (Wesarat, Sharif \& Majid, 2015).Employees who feel the happiness at work tend to focus more on their work and increase their productivities. Happiness at work is influenced by job satisfaction, job engagement, workplace security, managing stress and self-confidence. Furthermore, this paper will have a review of definitions, factors that influence happiness, the importance of happiness in the workplace and exposure to some of the results of previous research both outside and in Indonesia so that it can be an input for further research, remembering happiness is an important domain especially in life in the work environment.
\end{abstract}

Keywords: happiness, work happiness, employees, workplace

\section{Introduction}

Entering the $21^{\text {st }}$ century, the companies are no longer only focus on the expertise which have possessed by the employees. Moreover, the companies more focus on optimizing the quality and function, as well as the positive work experience that the employees have (Csikszentmihalyi, in Mauno, Kinnunen, \& Ruokolainen, 2007; Seligman \& Csikszentmihalyi, 2000).The employees work experiences are related to how mental health is working at the workplace. Work is the important aspect of one's life (Dulk, Groeneveld, Ollier-Malaterre, \& Valcour, 2013; Widyastuti \& Wulandari, 2014), where work is an important source for achieving the prosperity (Gavin \& Mason, 2004).The work environment plays an important role in the employee happiness (Pangarso, et al., 2016). Furthermore Warr (2007) added that work has become one of the key determinants of the employees' health and happiness. Happiness is a positive concept that is very important, especially in maintaining the health (Cohen, 2002).The happiness in the workplace is not only important for the employees themselves, but also for the organization (Chawsithiwong, 2007). The happy workers and good companies can create many good things such as increasing productivity, quality, sales, customer satisfaction, creativity, innovation, adaptation, flexibility, decreasing losses, absences, and decreasing the worker stress. 
Happiness is the most important goal that everyone in the world seeks for (Fisher, 2010). Everyone is looking for the happiness in a variety of ways (Aydin, 2012). Most of the people's daily thoughts and actions are aimed for achieving and maintaining the happiness (Tomasulo \& Pawelski, 2012).Working with him/herself, of course, cannot make a person happy, but a person cannot be truly happy if he/she is not happy at the workplace(Gavin \& Mason, 2004). When the workplaces are designed and managed to create the meaning for their workers, they tend to be healthier and happier.Thehealthy and the happy employees tend to be more productive in the long run, they able to produce the best goods and more satisfying services for the customers and the others. These three things - health, happiness, and productivity - are the important elements. By just increasing the productivity, which is almost the only emphasis of many organizations nowadays is certainly not enough (Gavin \& Mason, 2004).

Employees play an important role in the success of an organization or company. The company's progress depends on the quality of the employees themselves. This aim can be achieved if every employee has the happiness in the workplace. Of course it is also supported by a good working environment and its atmosphere as well as the balanced work tasks that make them feel at home and want to stay with their work. According to a survey conducted by Gallup (in Gupta, 2012), the happy employees are more ready to deal with the relationships at theworkplace, stress, and change.The companies that understand this case can increase their productivity by helping the employees to improve their welfare. Happiness in the workplace produces a good attitude towards the organization, which in turn leads to the efficiency and achievement of the organizational goals itself. This is the highest benefit an organization can obtain (Tseng, in Abraham, 2009).

Happiness is one of the important issues that need to be noticed, especially in the world of work. When employees feel happy in the workplace, they will be total in working so that the money is no longer the main thing. Due to the importance of this matter, several surveys were conducted to determine the condition of employees, whether they were happy or not especially in carrying out their work.A survey from the Jobstreet.com Indonesia in 2016 to 'Y Generation' stated that $33.4 \%$ of them were unhappy at the workplace. The cause of this unhappiness comes from the opportunities of limited career development, a number of less incentives and a rigid management leadership style (Khoiri, 2016). In line with these results, YouGov (Indra, 2017) conducted the survey to the productive employees in the UK aged 25-34 years found that the employees felt unhappy with the rhythm of working they did if compared to the employees in the other age groups.Another Jobstreet survey (Hari, 2017) conducted simultaneously in Indonesia, Hong Kong, Malaysia, Philippines, Singapore, Thailand and Vietnam, it was found that the happiness level of employees in Indonesia, Singapore, Malaysia and Vietnam increased if compared to the last year, unlike the case in the Philippines, Thailand and Hong Kong which actually declined.Another thing was found, that the employees felt that their situation would not improve in the next 6 months. In Indonesia alone, out of 100 people, $71 \%$ say that they are happy with their current job. The three main factors that make employees happy for their work, they are: the location of workplaces, the relationship among coworkers and the company reputation. While the things that make people unhappy is the lack of career development, the leadership and the training from the company.

Based on the results of the survey above, it seems so important that the company creates a happy work environment. Stress, unhappiness and psychological stress in the workplace are related to low productivity, decreased performance, increased risk of accidents, conflict in the workplace, increased absenteeism, increased sick leave, fatigue/burnout, high turnover rates, the emergence of various health problems, and increased costs of the care health (Warr, 2007).This is certainly related to how mental health and the psychological well-being of the employees in the workplace also study in positive psychology. Basically the goal of positive psychology is to help the people to enjoy their lives (Gavin \& Mason, 2004). Included in this matter is achieving their happiness, especially in the workplace. In the past decade, the happiness has been the most important main focus on positive psychology research where Seligman and Csikzsentmihalyi (2000) have focused on the individual happiness, positive conditions, and optimism. This finding became the origin of the study of 
happiness in the workplace and is also the opposite of previous studies which are more focused on depression, stress, pessimism and negative experiences (Stoia, 2015). Until now the topic of happiness has also spread to the workplace (Gupta, 2012).

The happiness appears in the form of pleasant moods and emotions, well-being, and the positive attitudes have attracted attention in psychological research (Fisher, 2010; Gupta, 2012). The happiness generally refers to the positive emotions which are felt by the individuals and the positive activities those are favored by the individuals too (Seligman, in Wulandari and Widyastuti, 2014).The individuals who work with the happiness are the individuals who have positive feelings at all the times. That is because the individual knows best how to manage and influence the world of his/her work so as to maximize performance and provide satisfaction in work (Pryce \& Jones, in Wulandari and Widyastuti, 2014).

The happiness in the workplace refers to the employees' satisfaction with their work and life (Wesarat, Sharif, \& Majid, 2015; Prasetyo, Ratnaningsih, \& Prihatsanti, 2017). The employees who feel happiness in the workplace tend to be more focused on working and increasing their productivity.The happy employees bring their happiness from the office to their home; likewise they also transfer their happiness from home to the office (Asiyabi \& Mirabi, in Wesarat, Sharif, \& Majid, 2015). Januwarsono (2015) adds that employees who are happy and enjoy working, when facing the most difficult situations they can handle it easily.

The term "happiness in the workplace" has to do with the job satisfaction, this is because the happy employees will be more satisfied with their work than the unhappy employees (Boehm and Lyubomirsky, 2008; Gupta, 2012; Januwarsono, 2015). In line with this, Tasnim (2016) added that the most significant cause that makes someone happy in the workplace is the job satisfaction. The job satisfaction encourages the employees to achieve and succeed in their work.

Some of the previous studies have shown a close relationship between the happiness and the success in the workplace (Gupta, 2012). The happy employees are relatively more successful in their workplaces. This is because of they performed the tasks better and tend to help the others if compared to the unhappy employees (Boehm and Lyubomirsky, 2008). In addition, the individuals who are physically happy can be happier, live longer and are able to adjust well in the face of challenges (Lyubomirsky, King, and Diener, 2005). Furthermore, the happiness leads to the success precisely through the influence of positive experience.

The previous research has shown a positive relationship between the happiness and the various indicators of success in the workplace. Compared to their less happy colleagues, happy people tend to make more money, showing a better job performance, and more often help their colleagues (Boehm \& Lyubomirsky, 2008; Lyubomirsky, King, \& Diener, 2005).Conversely, the unhappiness in the workplace can reduce the organizational productivity and also increase rates of absenteeism higher in the workplace (Gholipour, Najdi, \& Ekhtiari, 2013). It is important that organizations seek the prosperity and the happiness in the workplace, because it is not only benefits for the employees, but also the benefits for the organization, because the happiness in the workplace increases organizational productivity (Fisher, 2010; Rodríguez et al., 2010; Simmons 2014).Jessica Pryce-Jones (in Rao, et al., 2017) adds the happiness in the workplace with regard to utilizing all of the best-owned resources to overcome the challenges faced. This not only builds the individual happiness, but also the happiness of others who will be affected and energized by what is done.

The meta-analysis research about happiness found that the happiness leads to success in every area of our lives (such as marriage, health, friendship, community involvement, and creativity), especially at work, career, and business. In conclusion, the happiness is a competitive advantage for organizations that want to succeed by having happy and committed employees (Stoia, 2015). PryceJones (in Januwarsono, 2015; Stoia 2015) shows the results of the research on the extraordinary impact of the happy employees, including:

a) The happy employees are better able to achieve the higher levels of goals and challenges than the less of the unhappy employees; $18 \%$ more in the terms of changes and $33 \%$ more in the terms of goals. 
b) The employees who are happy in the workplace are $47 \%$ more productive than the unhappy employees.

c) There is a close relationship between the absence (sickness) and the happiness in the workplace. The happy employees are less absent than the unhappy employees.

d) The employees who are happy at work have 180\% more energy than the unhappy employees; this has a big impact not only on what they do but also on the relationships with their coworkers.

e) The happy employees $108 \%$ are more involved with their coworkers and also they are $82 \%$ more satisfied with their work.

f) The happy employees are $50 \%$ more motivated than the unhappy employees.

g) The happy employees have $28 \%$ more respect than the unhappy employees.

h) The employees who are happy $25 \%$ are more efficient and effective in their jobs, and $25 \%$ are more confident than the unhappy employees.

The research on happiness, especially in the workplace is still limited and needs to be developed continuously, so it is important to be investigated further. This is to obtain knowledge and information for the academics, practitioners and parties who are interested in discussing the topic of happiness in the workplace.The purpose of this paper is to explain the definition of work happiness, and also about the determinants of happiness in the workplace. In this literature review, it will also present some of the results of the previous research both the outside and in Indonesia, so that it can be an input for the further research, given that happiness is an important domain especially in life in the world of work.

\section{Method}

The method that the writer uses is the study of literature to collect the data, the information or sources which are related to the topics discussed. Through the literature studies the writer looks for the theoretical references that are relevant to the cases or problems found. The writer takes the source and conducts searches also reviews of several written sources from the books, journals, articles and all supporting references for writing the papers. Sources taken relate to the happiness in the workplace. The output of this literature study is the collection of references that are relevant to the problems studied.

\section{Discussion}

Will the employees who are happy while doing their work have a positive impact on working? Answering to this question, Tom Wright and Russell Cropanzano (in Januwarsono, 2015) emphasized that the employees who work happily will produce the high performance.They will be more sensitive in seeing opportunities that are more open and like helping their colleagues and also are more optimistic and confident. According to Maenapothi (in Januwarsono, 2015; Pangarso, et al., 2016) happiness in the workplace is a situation in a workplace where the employees like to work and do not feel burdened with their jobs, able to work efficiently and achieve targeted goals, both for themselves and their companies.

The happiness is often equated with the forms of mood or emotion (Rao et al., 2017). The term happiness is seen as an individual's positive feeling, satisfaction, pleasure, joy, and pleasure. The happiness in the workplace is the level of satisfaction of the employees and their feelings for work and performance. Happiness is the result of workplace practices or policies.Seligman (in Rao, et al., 2017) offers a more comprehensive view of happiness and defines it as "the individual quality of life, emotional health, work environment, physical health, and beneficial behavior". The five dimensions above form the content variables for happiness. 
The happiness in the workplace means positive emotions, experiences, positive attitudes (example job satisfaction, affective organizational commitment), personal development and feelings of purpose and also the significance of work that contribute to something valuable (Stoia, 2015).The happiness is the result of a process, which means that happiness in the workplace is not something that is sedentary or static. The employees can happily work at the one time and at the different times feel unhappy (Simmons, 2014). So that in this case it is important for organizations or companies to pay attention to any factors that can affect the happiness of individuals at work.

According to Pryce-Jones (2010), the happiness in the workplace depends on five factors: contribution (the effort you make), beliefs (the motivation you have), culture (how well you work), commitment (how you are involved) and trust self (believe in yourself and your work). Januwarsono (2015) found six determinants of happiness in the workplace, namely, the employee performance, organizational culture, organizational trust, job satisfaction, leadership behavior and the individual characteristics.Similar to these factors, Stoia (2015) also added the eight predictor factors of the happiness including employee performance, job characteristics, self-use and development, positive leadership behavior, positive feedback, positive experience in the workplace and the organizational culture.

According to Maenapothi (in Chaiprasit \& Santidhirakul, 2011) there are five factors that influence the happiness in the workplace, namely:

1. Job inspiration: employees are satisfied with the job assigned, and are able to reach the goal.

2. The value shared by the organization: the collective behavior and the culture of the organization.

3. Relationships: there are interactions, group ties and acceptance among the coworkers.

4. The quality of the work life: the relationship between 3 elements, namely the work environment, employee participation, and work humanization. A good balance between the 3 elements produces satisfaction which leads to the highest level of efficiency.

5. The leadership: the executives or the heads of organizations promote and create happiness for the employees when they work by creating motivation, awareness and dedication to their subordinates. The leaders also engage in 2-way communication and transparency with their staff and for themselves. All these are dedicated to creating a good atmosphere for their employees.

Wesarat, Sharif, and Majid (2015) have also developed a conceptual framework in understanding the work of happiness. Some of the factors that affect the work of happiness include factors that influence happiness in the workplace, namely employment status, income, friendship, and work activities, where all the four factors are moderated by the cultural value variables.The happiness depends on several factors that have different influences on each individual. Tasnim (2016) has identified several factors that influence happiness including: the job satisfaction, work attachment, workplace security, freedom, valued social position, stress management, work family conciliation, positive psychology, and self-esteem.

Associated with the determinant factors as a determinant of happiness, it can be seen that many factors form the happiness in the workplace. From the opinion of some experts, it can be concluded that the several factors that influence the work happiness include organization, personal and social factors.From the organizational factors related to the happiness are organizational culture, leadership, job characteristics, positive feedback, income and employment opportunities. Furthermore, the personal factors that determine of the happiness are related to the individual characteristics, selfesteem, job satisfaction, self-confidence, stress management, the employee motivation and engagement. The next determinant of happiness from social factors can be a social status, relationships with other people and friendships.

In addition to discussing the determinants of the happiness, the development of the study of happiness also has an impact on research within the organization or company. The researchers have also conducted several studies on happiness, the following are some of the results of research that discuss the work of happiness including: 
1. Pangarso, Pradana, Widodo and Putera (2016), conducted a study of 51 employees of the SDP Program (supervisor development program) at the Bank BTN Branch Harmoni, Jakarta. From the results of the study it was found that the leadership, work motivation, work relations, work skills, and work environment together had a contribution of $65.453 \%$ in determining of the work happiness. The leadership is the most dominant factor in determining the happiness.

2. The research that has been conducted by Januwarsono (2015) found six main factors determining of the happiness in employees of PT. PLN in Suluttenggo region, Sulawesi, namely: 1) the worker performance (competence, skills, seriousness, responsibility, timeliness, and productivity); 2) the organizational culture (harmonization in the workplace, employees of the most important assets, mutual trust among colleagues, mutual trust between boss and his/her subordinates (employees), and honesty);3) The organizational trust (the organizational commitment, human resource capabilities, infrastructure strength, company consistency); 4) The job satisfaction (the fairness of promotion, motivation, salary, and the coworkers support); 5) The leadership behavior (the trustworthy leaders, leaders as coworkers, leaders who can help subordinates, leaders as they should); 6) The individual characteristics (enjoying work, carrying out work without objections, feeling comfortable with the work, and dream jobs).

3. The research which has conducted by Wulandari and Widyastuti (2010) at the State Islamic University (UIN) Suska Riau, stated that the positive relationships with others, achievements, physical work environment, compensation and health are the sources of the happiness of workers. The positive relationships with the other people have the largest percentage (47.2\%) that makes someone happy in the workplace.This is because there is a support from the coworkers and supervisors who are wise. Furthermore, this research also proves there is no difference between male and female employees in mentioning the most dominant factors to support their happiness in the workplace.

4. Isriadi and Zulkarnain (2012), examined the relationship between the employee happiness and the employee engagement, the results showed that the employee happiness contributed $48.2 \%$ to the employee engagement. The workers will stay in the organization will be very dependent on how they see the future in the organization itself. A workplace that provides happiness will make employees stay with the company.

5. The research conducted by Lestiani (2016) found that there is a strong relationship between the self-acceptance and the happiness in the employees. The self-acceptance of someone is related to a good self-concept that will create a happiness.

6. Sousa \& Porto (2015), found that the organizational value has a relationship with the work happiness. If an organization wants to increase the level of happiness of its employees, then it must pay attention to the strongest characteristics of its organizational culture. Furthermore, it was found that the work value moderates the relationship between the organizational value and the work happiness.This means that when the organizations promote values that are similar to the values that are held by the employees, it will have a major impact on their happiness in the workplace.

7. Based on the results of Chaiprasit and Santidhirakul (2011) research in Thailand toward the employees who work on the small and medium size enterprises, it was found that the relationships, quality of work life, and leadership were the three main factors in predicting the work happiness. According to Chaiprasit and Santidhirakul, a good relationship will result in better communication, unity and altruism attitude among employees thus creating the work happiness. Furthermore, the findings prove that a good working environment will encourage the creation/realization of the healthy physical and mental strength.Regarding the leadership, according to Chaiprasit and Santidhirakul, the leaders must pay attention to their employees, especially in terms of communication, informing the employees about their performance, giving advice, and listening to their opinions and also build transparent 2-way communication.

8. Huang (2016) explored happiness in the workplace (subjective well-being) from 225 project management professionals. From the results of the study found factors that significantly influence 
happiness in the workplace. Namely, a pleasant work environment, an open organization and a well-managed team, and the right organization to work.

9. Abraham (2017) conducted a research to identify the factors that cause happiness among employees and to find a relationship between the happiness in the workplace and the job satisfaction. The results of the study showed that the personal resource factors, namely the sense of vitality, personal resilience and personal happiness are the factors that produce the happiness in the workplace. Furthermore, along with these factors the respondents were happy because they worked in well-managed teams and had a manager whom they could trust. Another Abraham study found that the happiness in the workplace has a relationship with the job satisfaction with a contribution of $32.3 \%$.

Based on the results of the above research, the further research is still needed, considering that in Indonesia itself the research and application of the happiness studies are still limited. Especially those that have been published. Some of the results of many studies that examine the happiness are determined by the external factors. Therefore, it is necessary to do research by looking at the happiness from the individual characteristics, given that happiness itself arises from within the individual's self.

\section{Conclusions}

Many studies have proven that if employees are happy, then they tend to be more productive, can produce the innovations with the new ideas, able to try to do the same work with more innovative methods to save time and can increase the effectiveness (Gupta, 2012). The happiness is a concept that is now being researched much in psychology and extends to the workplace.The happiness in the world of work is influenced by the organization, personal and social factors (Tasnim, 2016). Future research should be able to develop a conceptual model and to conduct research by combining extrinsic and intrinsic factors in studying the happiness so as to provide a broader understanding of the concept of happiness, especially in the workplace.

Based on the previous explanation, it is important for companies to create and manage workplaces that are able to encourage the emergence of the happiness and welfare for their employees. This can be done by giving more emphasis to the application of positive psychology values by paying attention to the determinants of the work happiness. To create a healthy and happy workplace, the organizations must focus on developing the positive psychological concepts. Organizations must be designed in such a way as to involve several of these factors so that they can create the happiness in the workplace.

\section{References}

Abraham, S. (2017). Factors influencing workplace happiness among employees in software companies in Bangalore. International Journal of Research in Applied Management, Science and Technology,2(2). Retrieved from $\quad$ http://zenonpub.com/images/pdf-files/Vol2Issue2/3SusanAbraham.pdf

Aydin, N. (2012). A grand theory of human nature and happiness. Humanomics, 28(1), 42-63. doi: $10.1108 / 08288661211200988$

Boehm, J. K., \& Lyubomirsky, S. (2008). Does happiness promote career success?. Journal of Career Assessment, 16 (1), 101-116. doi:10.1177/1069072707308140

Chaiprasit, K., \& Santidhirakul, O. (2011). Happiness at work of employees in small and mediumsized enterprises, Thailand. Procedia - Social and Behavioral Sciences, 25, 189-200. doi:10.1016/j.sbspro.2011.10.540.

Chawsithiwong, B. (2007). Happy workplace. Journal of Social Development, 9(2), 61-93. Retrieved from https://tci-thaijo.org/index.php/jsd/article/view/31228 
Cohen, S.B. (2002). Happiness and the immune system. Positive Health, 82. Retrieved from http://www.positivehealth.com/article/emotions-beliefs/happiness-and-the-immune-system

Dulk, L. D., Groeneveld, S., Ollier-Malaterre, A., \& Valcour, M. (2013). National context in work-life research:A multi-level cross-national analysis of the adoption of workplace work-life arrangements in Europe. European Management Journal, 31, 478-494. doi: 10.1016/j.emj.2013.04.010

Fisher, C. D. (2010). Happiness at work. International Journal of Management Reviews, 12, 384-412. doi: 10.1111/j.1468-2370.2009.00270.x

Gavin, J.H., \&Mason, R.O. (2004). The value of happiness in the workplace. Organizational Dynamics, 33, 379-392. doi: 10.1016/j.orgdyn.2004.09.005

Gholipour F. H., Najdi, Y., \& Ekhtiari A, R. (2013). Do governance factors matter for happiness in the MENA region?.International Journal of Social Economics, 40(12), 1028-1040. doi:10.1108/ijse-112012-0208

Gupta, V. (2012). Importance of being happy at work. International Journal of Research and Development, 1(1), 9-14. Retrieved from http://www.irdindia.in/journal ijrdmr/pdf/vol1 iss1/2.pdf

Hari, A. (2018). 71 Karyawan di Indonesia mengaku bahagia dengan pekerjaannya. Retrieved from http://www.intipesan.com/71-karyawan-di-indonesia-mengaku-bahagia-dengan-pekerjannya/

Huang, H. (2016). Workplace happiness: organizational role and the reliability of self-reporting. Thesis (Unpublished). Master of science in civil engineering. University of maryland, college park. Retrieved from https://drum.lib.umd.edu/bitstream/handle/1903/18191/Huang umd 0117N 16920.pdf?sequence $=1$

Indra, R. (2017). Survei: karyawan 25-34 tahun tak bahagia dengan ritme kerja. Retrieved from https://www.cnnindonesia.com/gaya-hidup/20170320162818-277-201490/survei-karyawan-25-34tahun-tak-bahagia-dengan-ritme-kerja

Isriadi, T.S \& Zulkarnain. (2012). Kaitan antara kebahagiaan pekerja dan employee engagement studi empirikal.Jurnal Magister Psikologi UMA. 4(2), 91-96. Retrieved from http://ojs.uma.ac.id/index.php/analitika/article/view/781/774

Januwarsono, S. (2015). Analytical of factor determinants of happiness at work case study on PT. PLN (Persero) Region suluttenggo, Sulawesi, Indonesia. Europeanjournal of Business and Management, 7(8), 9-17. Retrieved from https://www.iiste.org/Journals/index.php/EJBM/article/viewFile/20937/21502

Khoiri, A. (2016). 33 persen pekerja Indonesia tidak bahagia. Retrieved from https://www.cnnindonesia.com/gaya-hidup/20160722101825-277-146292/33-persen-pekerjaindonesia-tidak-bahagia?

Lestiani, I. (2016). Hubungan penerimaan diri dan kebahagiaan pada karyawan. Jurnal Ilmiah Psikologi.9(2),

109-119.

Retrievedfromhttp://ejournal.gunadarma.ac.id/index.php/psiko/article/view/1549/1308

Lyubomirsky, S., King, L., \& Diener, E. (2005). The benefits of frequent positive affect: does happiness lead to success?.Psychological Bulletin, 131(6), 803-855. doi: 10.1037/0033-2909.131.6.803

Mauno, S., Kinnunen, U. \& Ruokolainen, M. (2007). Job demands and resources as antecedents of work engagement: A longitudinal study. Journal of Vocational Behavior, 70, 149-171. doi: 10.1016/j.jvb.2006.09.002

Pangarso, A., Pradana, M., Widodo, A., \& Putera, K. D. B. (2016). Bank's employees happiness factor analysis (a study in bank BTN Harmoni branch, Jakarta, Indonesia). Retrieved from https://astadipangarso.staff.telkomuniversity.ac.id/files/2014/01/WISS Astadi Tel-U-revision.pdf

Prasetyo, A. R., Ratnaningsih, I. Z., \& Prihatsanti, U. (2017). Bahagia di Tempat Kerja. Edisi 1. Yogyakarta: Spektrum Nusantara.

Price-Jones, J. (2010). Happiness at Work: Maximizing your PsychologicalCapital for Success (Oxford, UK: Wiley, 2010).Book review. page 275-276. Retrieved from http://journals.sfu.ca/rpfs/index.php/rpfs/article/download/129/128 
Rao, G. V., Lakshmi, V., \&Goswami, R. (2017). A study on factors of workplace happiness. International Journal of Marketing \& Financial Management. 5(8), 27-42, doi url: http://doi.org/10.5281/zenodo.888497

Rodríguez, R.C., Moreno, M.J., Rivas, S.H., Álvarez, A.B., and Sanz, V.I. (2010). Positive psychology at work: mutual gains for individuals and organizations. Revista de la psicología del trabajo y de las Organizaciones, 26(3), 235-253. doi: 10.5093/tr2010v26n3a7

Seligman, M.E.P. and Csikszentmihalyi, M. (2000). Positive psychology: an introduction. American Psychologist, 55(1), 5-14. doi: 10.1037/0003-066X.55.1.5

Simmons, B.L. (2014). Organizational characteristics of happy organizations. In P. Y. Chen, \& C.L. Cooper (Eds.), Work and wellbeing: Wellbeing: A Complete Reference Guide, Vol III. (pp. 1-18). Hoboken: John Wiley \& Sons, Inc. Retrieved from https://onlinelibrary.wiley.com/doi/pdf/10.1002/9781118539415.wbwell023

Sousa, J. M. D., \& Porto, J. B. (2015). Happiness at work: organizational values and personorganization fit impact. Paiceia, 25(61), 211-220. doi :10.1590/1982-43272561201509

Tasnim, Z., (2016). Happiness at workplace: building a conceptual framework. World Journal of Social Sciense. 6(2),62-70. Retrieved from http://www.wjsspapers.com/static/documents/July/2016/6.\%20Zerin.pdf

Tomasulo, D. J., \& Pawelski, J. O. (2012). Happily ever after: the use of stories to promote positive interventions. Psychology, 3, 1189-1195. doi: 10.4236/psych.2012.312A176

Warr, P. (2009). Work, happiness, and unhappiness. Cognitive Behavioral Therapy Book Reviews. 5(5), Institute of Work Psychology, University of Sheffield. Retrieved from https://www.theiacp.com/assets/CBTBR/cbtbr-vol 55a.pdf

Wesarat, P., Sharif, M. Y., \& Majid, A. H. A. (2015). A conceptual framework of happiness at the workplace. Asian SocialScience, 11(2),78-88. doi: 10.5539/ass.v11n2p78

Wulandari, S \& Widyastuti, A. (2014). Faktor - faktor kebahagiaan di tempat kerja. Jurnal Psikologi. 10(1), 49-60. Retrieved from http://ejournal.uinsuska.ac.id/index.php/psikologi/article/view/1178/1070 